\title{
GREAT LAKES NATURAL RESOURCE GOVERNANCE SYMPOSIUM: THE GOOD GOVERNANCE WATERSHED
}

\section{Cameron Davis*}

The Indiana University Robert H. McKinney School of Law's students have done a tremendous service to the region--and the nation, since the Great Lakes hold some 95 percent of the country's fresh surface water-by hosting its symposium on Great Lakes Natural Resource Governance. ${ }^{1}$ In the day-to-day scramble to understand issues, make decisions, implement them, then test those decisions, we do not often get the chance to hit the pause button to ensure this entire system of decisionmaking is working as well as it should. The thinking supporting this symposium is a rare chance to do just that.

In close to three decades of doing Great Lakes work, I have seen how it is all too easy to rely on reading a quick headline or focusing on a single issue to judge whether our system of decision-making is effective. But "good governance"-the process of making, implementing, and refining our decisions - is not just about a single issue or policy. It is about how tens of millions of people use the Great Lakes every year.

They fish in the Great Lakes.

They play in the Great Lakes.

They have jobs because ships, for example, carry large amounts of food, fuel, and raw materials from one place to another.

They turn to the Great Lakes for spiritual renewal.

They understand that our health as people is linked to the health of other living organisms that rely on the Great Lakes.

And they drink the Great Lakes, often without thinking for a second about issues or policy.

* For information about the author, see Cameron Davis, Senior Advisor to the Administrator, ENVTL. PROTECTION AGENCY, http://www2.epa.gov/aboutepa/cameron-davissenior-advisor-administrator (last visited Oct. 12, 2013, archived at $\mathrm{http}: / /$ perma.cc/0YMTSBuX6qn). The opinions expressed herein are those of the author. They do not reflect EPA policy, endorsement, or action, and the EPA does not verify the accuracy of the statements made herein.

1. The Great Lakes Natural Resource Governance Symposium was held on March 1, 2013, at Indiana University Robert H. McKinney School of Law in Indianapolis, Indiana. 
In my own role helping to coordinate eleven federal departments that are part of the Great Lakes Interagency Task Force (Task Force), ${ }^{2}$ I walk into the room as a professional. I also walk into that room, however, as a father of two children whom I like to take to the beach and whom I would like to see grow up to enjoy the Great Lakes with their grandchildren. These are the kinds of uses and aspirations good governance must support.

\section{WHAT IS "GOOD GOVERNANCE?"}

So, what is "good governance?" I believe it is the process of informing, making, implementing, and refining our decisions on specific issues with specific policies to advance these uses and aspirations. It supports these uses and aspirations so the health and prosperity of those who live, work, and play in this region endless generations from now are at least as strong as the health and prosperity of our generation. In contrast, poor Great Lakes governance is comprised of decisions that benefit the health and prosperity of one or more generations over the health and prosperity of other generations. ${ }^{3}$

Good governance should be able to underpin any one of the challenges discussed at the symposium-invasive species and water use, for example-and advance these uses and aspirations.

Now, if we know what good governance should achieve, how does good governance achieve it? What does it include? What does good governance look like?

You can picture good governance as a watershed. At the center is a lake - or you can use any other basin-as the culmination of decisions that benefit all generations, not just a few. Good governance is fed by different tributaries, the different kinds of practices and efforts that I will detail. I will use federal efforts, especially the Great Lakes Restoration Initiative (GLRI), ${ }^{4}$ to help bring this metaphor to life. The GLRI is an Initiative

2. The Interagency Task Force was established by Executive Order in 2004. See Exec. Order No. 13,340, 69 Fed. Reg. 29,043 (May 20, 2004), archived at http://perma.cc/0d8MiUnwXzD; See also Great LaKes Restoration InITIATIVE: ACTION PLAN (2010) [hereinafter ACTION PLAN 2010], archived at http://perma.cc/0AmBMXRwt6t. The U.S. Department of Health and Human Services was added after Executive Order 13,340 was signed. See Great Lakes Restoration Initiative Action Plan (2010), last visited Nov. 24, 2013, archived at http://perma.cc/GL4T-UN6M.

3. The temporal aspect of good governance is similar to the concept of "sustainability," which was recently added as a principle under article 2(4)(m). Agreement between the United States of America and Canada on Great Lakes Water Quality, 2012, U.S.-Can., art. 2, Sept. 7, 2012 [hereinafter GLWQA], archived at $\mathrm{http}: / /$ perma.cc/0QrdBn68TqG (stating that sustainability is "considering social, economic and environmental factors and incorporating a multi-generational standard of care to address current needs, while enhancing the ability of future generations to meet their needs.").

4. Great Lakes Restoration Initiative, http://glri.us/ (last visited Nov. 4, 2013, 
President Obama proposed and for which Congress appropriated, starting in federal fiscal year $2010,{ }^{5}$ several hundred million dollars ${ }^{6}$ for investment in five "focus areas:"

\section{Cleaning up toxic hotspots called "Areas of Concern;"}

Controlling and preventing invasive species, such as Asian carp, from becoming established;

Reducing polluted runoff that undercuts nearshore health;

Expanding fish and wildlife habitat; and progress. $^{7}$

Supporting education, coordination, partnerships, and tracking

When the federal agencies released the Action Plan with many of the region's governors, Washington Post commentator David Broder called the GLRI:

a truly bipartisan and binational enterprise, involving leaders and groups from eight states, innumerable communities, [and] the two major U.S. political parties.... The 30 million people who live in this region make it a major political battleground. In an age of rampant distrust, I can't think of a better way to show that government can work. ${ }^{8}$

With that as an example, what are the elements-the tributaries—of good governance?

\section{THE GOOD GOVERNANCE “TRIBUTARIES”}

\section{A. Good Science}

One of the "tributaries" to good governance is good science. The

archived at $\mathrm{http} / / /$ perma.cc/0r2WGnXjMmF).

5. The federal fiscal year runs October 1 through September 30 of the following year. Fiscal Year 2010 was October 1, 2009, through September 30, 2010. See Glossary: Fiscal Year, U.S. SENATE, http://www.senate.gov/reference/glossary_term/fiscal_year.htm (last visited Nov. 4, 2013, archived at http://perma.cc/0TEu7XcN8Uz).

6. See David S. Broder, Op-Ed., Great Goals for the Great Lakes, WASH. Post (Feb. 25, 2010), archived at http://perma.cc/0raNbN8Su6W.

7. See ACtion Plan 2010, supra note 3, at 4.

8. Broder, supra note 7. 
good science tributary has several streams that feed into it, too. Good science is objective. It is accessible and understandable to people who are not scientists. It accounts for ecosystem dynamism, the notion that like us as individuals, ecosystems do not stay static. ${ }^{9}$ They change constantly. Good science also must provide a factual platform from which all decisions can be made.

Now that we have identified one tributary to the sound decisionmaking goal of good governance, let me make the metaphor real using the GLRI. The GLRI is supporting "the first-ever comprehensive assessment of the entire 530,000 acres of Great Lakes coastal wetlands." ${ }^{\prime 0}$ The assessment is intended to help agencies target restoration and protection efforts. In other words, the GLRI is funding an objective, accessible, factual platform about the state of the region's wetlands that will help us pinpoint where we should implement wetland restoration work in the future. ${ }^{11}$ Wetlands, as we know, improve water quality, reduce flooding and property damage, and provide fish and wildlife habitat, among other benefits. ${ }^{12}$

Another real-life example of science as an underpinning to good governance is that when Congress appropriated funds for the GLRI, it required an independent scientific review of the GLRI Action Plan. ${ }^{13}$ To its credit, Congress wanted to ensure the dollars it was appropriating were and are being used effectively. ${ }^{14}$ In January 2012, the EPA's Science Advisory Board completed its independent scientific review of the Action Plan and concluded that "enough is known about the issues confronting the Great Lakes, as well as the underlying causes and potential remedies, to initiate action, and [the Science Advisory Board] agrees that the [GLRI] Action Plan identifies most of the important actions that should be undertaken."15

9. VANDEwalle et al., Review PaPer on CONCEPTS OF DYNAMic ECOSYSTEMS AND THEIR SERVICES 8 (n.d.).

10. ACTION PLAN 2010, supra note 3, at 4.

11. See id. at 5 .

12. See VANDEWALLE ET AL., supra note 10 , at 10.

13. ACTION Plan 2010, supra note 3, at 14.

14. The Conference Report accompanying H.R. 2996 states that the EPA shall consider:

That independent scientific reviews are the preferred method for some elements and activities to ensure that the best available science guides efforts to restore the Great Lakes. However, the Agency may selectively use and scale these scientific reviews so that the rate of progress is optimized at the same time scientific validation is ensured. The Agency shall determine those elements for which additional scientific validation is needed to expedite restoration while providing the Agency with the basis for optimizing successful restoration programs and projects to advance the goals, objectives, and restoration priorities of the action plan.

H.R. REP. No. 111-316, at 111-12 (2010) (Conf. Rep.).

15. Letter from Dr. Judith Meyer, Acting Chair, Sci. Advisory Bd., to Hon. Lisa P. Jackson, Adm'r, Envtl. Prot. Agency (Jan. 24, 2012), archived at 


\section{B. Effective Collaboration}

Another contribution to good governance is effective collaboration. Several streams feed effective collaboration, making it one of the largest and most important tributaries. Effective collaboration requires planning ahead and including in that plan who is supposed to be in charge of doing what and by when. Inclusivity is also critical, ensuring that an appropriate and diverse set of voices is at the table. For example, here in the Great Lakes region, we have federal agencies, active governors, mayors, tribes, public interest organizations, businesses, academia, and many other constituencies that have an important place in supporting strong decisionmaking. ${ }^{16}$

Effective collaboration also ensures that upstream and downstream constituencies work together to address sources and effects of pollution. One of the most important streams is an actively engaged citizenry. Without it, effective collaboration cannot happen and governance dries up. As previously mentioned, one of the first things the Task Force did was establish the GLRI Action Plan in 2010. This is an example of planning. Also, as an example of "who" is at the table, the Task Force coordinates the work of eleven federal departments to make investments under this Action Plan.

\section{Policy}

Also flowing into good governance is good policy. I believe good policy is based on good science and effective collaboration. But good policy makes the best use of various tools, such as legislation, treaties, executive agreements, regulations, executive orders, guidance, and memoranda of understanding. This list goes on, but the point is that good governance is comprised of the "rules of the road," a clear articulation of behaviors that are expected of each of us to address the kinds of issues discussed at the symposium.

One example of good policy is the presidential executive order that established the Task Force mentioned above, ${ }^{17}$ which is comprised of federal departments that help drive ecosystem restoration investments. ${ }^{18}$ Another example of good policy is the Great Lakes Water Quality

http://perma.cc/0g6Scq4FSrl (first alteration added).

16. In December 2004, stakeholders came together to develop the Great Lakes Regional Collaboration Strategy, which later served as a foundation to the GLRI Action Plan. See GREAT LaKes Regional CollaboRation, http://www.glrc.us (last visited Aug. 29, 2013, archived at http://perma.cc/0uVb6CDKwAy).

17. See supra notes 5-9 and accompanying text.

18. See Exec. Order No. 13,340, 69 Fed. Reg. 29,043 (May 20, 2004), archived at http://perma.cc/0d8MiUnwXzD. 
Agreement. ${ }^{19}$ This executive agreement between the United States and Canada commits the two countries to coordinate to restore and maintain the chemical, physical, and biological integrity of the Great Lakes. ${ }^{20}$

\section{Accountability}

Another tributary that feeds good governance is accountability. Accountability is the suite of mechanisms that we use to ensure compliance with policy.

One form of accountability is voluntary incentives, such as funding. Market-based approaches to fixing ecological problems are getting increased attention, as are the elimination of subsidies. ${ }^{21}$ Another kind of accountability is enforcement, where the failure to comply with policy can result in penalties. Transparency is also an important feeder for accountability.

Yet another mechanism for accountability is assessment: making sure that we examine the decisions we have made and refine them over time to ensure they are even more effective. The Science Advisory Board undertook an independent scientific review of the GLRI Action Plan, ${ }^{22}$ which exemplifies assessment as a form of accountability. When the Science Advisory Board issued its report, it recommended scientific assessments be conducted to review the effectiveness of GLRI funding for projects. ${ }^{23}$ The goal is to learn from our investments and refine our decision making over time. Recall, at its core, good governance is about good decisions.

\section{E. Good Leadership}

In some ways, the most important tributary to good governance may be leadership. Good leaders have a vision for the way things should be a year from now, ten years from now, and beyond, to ensure health and prosperity for all generations. Leaders are unrelenting in their commitment to getting things done. They are accountable for ensuring that the process of deliberation and collaboration leads to the product of ecological results. They are informed by good science and have a good sense of which policy tools or combination of tools should be used to achieve those ecological

19. GLWQA, supra note 4.

20. See Kim Mackrael, Canada, U.S. Set to Sign Updated Great Lakes Accord, THE GLOBE AND MAIL (Sept. 7, 2012), archived at http://perma.cc/0j1RnGbGgBt.

21. See generally Ted Gayer \& John K. Horowitz, Market-Based Approaches to Environmental Regulation, 1 FOUND. \& TRENDS IN MICROECONOMICS 201 (2005), archived at http://perma.cc/0nZMGL6NFqS.

22. See generally Letter from Dr. Judith Meyer to Hon. Lisa P. Jackson, supra note 16.

23. Id. at 2 . 
results.

\section{CONCLUSION}

Now, here are some qualifiers. First, the elements to good governance are not necessarily exclusive. For example, transparency is an element of accountability, effective collaboration, good leadership, and other tributaries. Second, governance may look a little different for each watershed, just like each watershed is different, as the Comparative Models panel expertly demonstrated during the symposium. The Great Lakes governance model, which encompasses two countries with about forty tribes, may be different from the model for the Chesapeake Bay, which is contained wholly within the United States. Third, there may be other tributaries, or elements to good governance. The list I have given is not exhaustive.

In the meantime, healthy watersheds depend on healthy governance. And that, in turn, depends on understanding what makes good governance work. 
